OPEN ACCESS

Edited by:

Laurent Dufossé,

Université de la Réunion, France

Reviewed by:

Samantha Chandranath Karunarathna,

Kunming Institute of Botany (CAS),

China

Fengli Zhang,

Shanghai Jiao Tong University, China

${ }^{*}$ Correspondence: Weibing Zhang 45330301@qq.com Zhongming Zhang

270154787@qq.com

${ }^{t}$ These authors have contributed equally to this work

Specialty section:

This article was submitted to Food Microbiology, a section of the journal

Frontiers in Microbiology

Received: 19 January 2021 Accepted: 04 June 2021

Published: 25 June 2021

Citation:

Zhang M, Qiao H, Zhang W, Zhang Z, Wen P and Zhu Y (2021)

Tissue Type: A Crucial Factor Influencing the Fungal Diversity and Communities in Sichuan Pork Bacon. Front. Microbiol. 12:655500. doi: 10.3389/fmicb.2021.655500

\section{Tissue Type: A Crucial Factor Influencing the Fungal Diversity and Communities in Sichuan Pork Bacon}

\author{
Miao Zhang ${ }^{1 \dagger}$, Haijun Qiao ${ }^{2 \dagger}$, Weibing Zhang ${ }^{1 *}$, Zhongming Zhang ${ }^{1 *}$, Pengchen Wen ${ }^{1}$ \\ and Yan $\mathrm{Zhu}^{1}$ \\ ${ }^{1}$ College of Food Science and Engineering, Gansu Agricultural University, Lanzhou, China, ${ }^{2}$ College of Science, Gansu \\ Agricultural University, Lanzhou, China
}

This study aimed to the variations of fungal diversity and community structure in different parts of traditional homemade Sichuan pork bacon. A total of seven phyla and 91 fungal genera were identified. Among them, Ascomycota and Basidiomycota were the first and second most abundant phyla in the bacon tissues. In addition, five dominant genera (Aspergillus, Candida, Debaryomyces, Malassezia, and Penicillium) were shared by all bacon tissues. The numbers of OTUs unique to individual groups were 14, 67, and 65 for the muscle tissue, the adipose tissue, and pork skin, respectively. Linear discriminant analysis showed that a total of 31 taxa significantly differed among the groups. Results of redundancy analysis indicated that fat content, protein content, aw, and $\mathrm{pH}$ of bacon tissue shaped the bacon fungal communities. Results of network analysis also indicated that tissue type was a crucial factor influencing the fungal interactions in different tissues. This study can lay a foundation for further isolation and identification of fungi in the product and provides a basis for further research of food health in homemade traditional pork bacon.

Keywords: traditional pork bacon, tissue, high-throughput sequencing, physicochemical characteristics, microbial interaction

\section{INTRODUCTION}

Chinese pork bacon, a famous traditional meat product, possesses a long history in southern China (Wang et al., 2019; Huang et al., 2020). A variety of traditional Chinese pork bacon styles such as Hunan, Sichuan, Guangdong, Jiangxi, and Yunnan styles have been produced and favored by local people (Yu and Sun, 2005). Among them, Sichuan-style is one of the most famous smoked styles (Guo et al., 2016; Wang et al., 2019). The traditional preparation process of Sichuan pork bacon generally consists of cutting, curing, smoking, and ripening. It is usually prepared in the winter of each year to ensure an adequate supply of meat available for next spring (Guo et al., 2016). Due to its delicious taste and flavor, Sichuan pork bacon is being favored by many people in China (Xie et al., 2008; Guo et al., 2016).

The quality of traditional meat products is often greatly influenced by environmental microorganisms (Bernardi et al., 2019). During the production of these products, the surface of the raw meat is exposed to the environment, so naturally-occurring microorganisms may colonize (Doulgeraki et al., 2012). Abundant and diverse fungal populations, including Aspergillus, Mucor, Penicillium, and yeast have been found in this specific food ecosystem (Mendoza et al., 2014; Magistà et al., 2017). Some of them can endow meat products with good flavor, anti-oxidative effects 
and protection role against detrimental microorganisms (Magistà et al., 2017; Ryu et al., 2018; Rodrigues et al., 2019). Some can also lead to undesirable effects, such as unsightly colored spots, offflavors or toxic fungal metabolites (Ryu et al., 2018; Rodrigues et al., 2019). Because of the lack of information concerning fungi on the surface of Sichuan pork bacon, no quality standards regarding these organisms exist. Therefore, it's necessary to investigate the fungal communities of this product.

In the production of bacon, fresh streaky pork is often used as the raw material, which includes the muscle tissue, the adipose tissue, and pork skin. Because of obvious differences in the tissue status and physicochemical properties of these different parts, they may affect the species of attached microorganisms (Ellis et al., 1983). Previous studies have shown that climate, geography, and processing technology have impacted the bacterial communities in the bacons (Yi et al., 2016). However, there have been few reports on the effect of tissue type of raw meat on the fungal community structure in traditional homemade pork bacon. In this study, our objective was to make an inventory of the diversity and interactions of the fungal communities in different tissues of homemade traditional bacon using Illumina Miseq metabarcoding.

\section{MATERIALS AND METHODS}

\section{Sample Collection}

Homemade bacon samples were collected directly from six local producers in Lacquer Tree village, Fan Kuai town, Xuanhan County and Dazhou City (Sichuan Province, China). The processing technology of the bacon is presented in Figure $\mathbf{1}$. Five bacon sticks were randomly collected from each producer. The samples were packed in sterile bags and transported to the laboratory. In sampling, bacon tissues around $2 \mathrm{~mm}$ from the surface were sliced using a sterilized knife. Each bacon sample was divided into three parts based on the tissue of bacon; the first part included the sample from the adipose tissue (F), the second part included the sample from the muscle tissue $(\mathrm{M})$, and the third part included the sample from the pork skin (P). Then, newly collected samples were directly used for physicochemical and microbiological analysis and the samples for high-throughput sequencing were stored at $-80^{\circ} \mathrm{C}$.

\section{Physicochemical Analyses}

Protein, fat, and moisture content were determined according to the Chinese Standard GB 5009.5-2016, GB 5009.6-2016, and GB 5009.3-2016 procedures, respectively (Guo et al., 2016). Salt content was measured on the basis of the Chinese Standard GB 5009.42-2016 procedures (Guo et al., 2016). $\mathrm{a}_{\mathrm{w}}$ (water activity) was determined using a water activity meter (Novasina, Switzerland) while $\mathrm{pH}$ was measured using a digital $\mathrm{pH}$ meter (Sartorius, Germany).

\section{Microbial Enumeration}

Microbial enumeration was conducted according to the method described by $\mathrm{Li}$ et al. (2019). Samples (25 g) were added aseptically to $225 \mathrm{~mL}$ of sterile Buffered Peptone Water (Merck,
Darmstadt, Germany), and homogenized for 2 min within a stomacher (Interscience, Saint Nom la Bretèche, France). Decimal dilutions were prepared in Ringer's solution (LabM, Bury, United Kingdom) for microbial enumeration. Then aliquots of $0.1 \mathrm{~mL}$ were spread on the following growth media for the following microbial viable counts: Aerobic plate counts on Plate Count Agar (PCA, LabM) incubated at $30^{\circ} \mathrm{C}$ for 3 days; Xerophilic fungi on Dichloran 18\% Glycerol Agar (DG18, Hopebio), incubated at $25^{\circ} \mathrm{C}$ for 5 days; Yeasts and molds on Rose Bengal (RB, Lang Bridge), incubated at $25^{\circ} \mathrm{C}$ for 5 days.

\section{DNA Extraction, PCR Amplification, and Sequencing}

Each sample (25 g) was homogenized with $225 \mathrm{~mL}$ of peptone saline solution $(0.85 \% \mathrm{NaCl}$ and $0.1 \%$ peptone in distilled water) for $30 \mathrm{~min}$ within a stomacher. $20 \mathrm{~mL}$ quantities of the solution were centrifuged for $10 \mathrm{~min}$ at $9,000 \times g$, and the pellet was used to extract genomic DNA with a Soil DNA Kit D5625-01 (Power Soil DNA Isolation kit, MOBIO Laboratories, Inc., United States) according to the manufacturer's instructions.

The ITS rDNA gene targeting the ITS1-ITS2 region was amplified using the primer pairs ITS1-F (CTTGGTCATT TAGAGGAAGTAA) and ITS2 (GCTGCGTTCTTCATCGA TGC), as previously described (Luo et al., 2020). Subsequently, the library was constructed and the isolated DNA was sequenced on an Illumina Miseq PE300 Sequencing platform (Illumina, Inc., San Diego, CA, United States) at Biomarker Technologies Corporation (Beijing, China). Then, the sequencing data were uploaded into the Sequence Read Archive at NCBI under the accession number PRJNA610642.

\section{Processing of High-Throughput Sequencing Data}

The pair-end reads from raw DNA sequences were conducted using the FLASH software (Magoc and Salzberg, 2011). Data quality control and analysis were mainly conducted using the software package of QIIME ${ }^{1}$ (Caporaso et al., 2010). The highquality sequences were obtained by discarding the low-quality sequences from raw data, including sequences shorter than $150 \mathrm{bp}$, with any ambiguous bases, containing mononucleotide repeats more than 6, Phred score below 25, or chimeric sequences (by QIIME). Quality sequences were classified into operational taxonomic units (OTUs) with a cutoff of 97\% identity, by the QIIME-uclust OTU-picking workflow. Taxonomies were annotated using the UNITE databases (Koljalg et al., 2013) by a QIIME-based wrapper of RDP-classfier (v.2.2). To minimize the difference in sequencing depth across samples, an averaged, rounded, and rarefied OTU table was generated by averaging 100 evenly re-sampled OTU subsets under the $90 \%$ of the minimum sequencing depth. Alpha diversity indices of Chao1, Shannon, and Good's coverage for the tissues were calculated using QIIME(V 1.9.1). Non-metric Multidimensional Scaling (NMDS) was conducted to analyze the differences between the tissues using $\mathrm{R}$ software (version 2.15.3). The Adonis permutational

\footnotetext{
${ }^{1}$ http://qiime.org/
} 
Salting at $15-20{ }^{\circ} \mathrm{C}$ for $7-8 \mathrm{~d}$

(Temperature $15-20{ }^{\circ} \mathrm{C}$, relative humidity $70-90 \%$ )

Smoking and ripening for 30-60 d

(Temperature $45-50{ }^{\circ} \mathrm{C}$, relative humidity $70-85 \%$ )
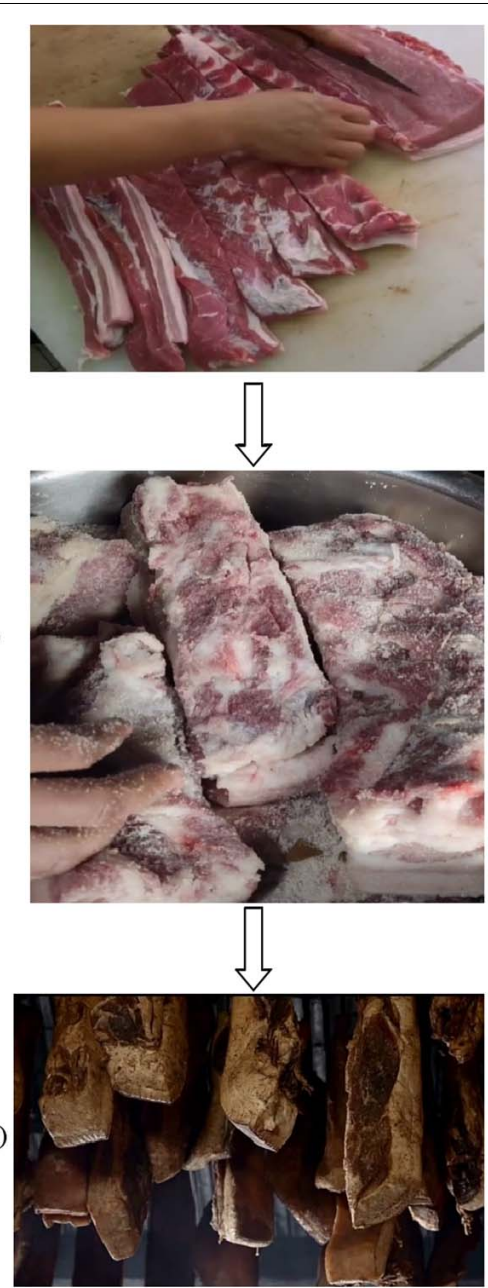

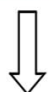

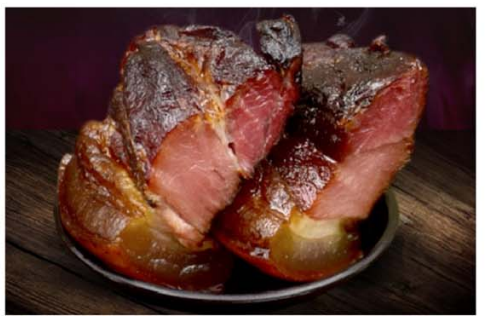

Bacon

FIGURE 1 | A schematic diagram of the production of homemade pork bacon.

multivariate analysis (Adonis/PERMANOVA) were used to test the statistical difference of fungal structure among the tissues (Lozupone et al., 2007). LEfSe (Linear discriminant analysis Effect Size) was conducted to identify differentially abundant taxa between different tissues (LDA score $\geq 3.0$ and $p \leq 0.05$ ) (Segata et al., 2011). The SparCC algorithm was used to analyze the correlation of fungal genera in the bacon tissues, including positive correlation and negative correlation (Friedman and Alm, 2012). Statistical analysis was also performed on the screening of the correlation score $>0.6$ with a significance level less than
0.05. Networks analysis was conducted using the biocloud tools, as previously described (Luo et al., 2020). Redundancy analysis (RDA) was also implemented using the biocloud tools.

\section{Statistical Analysis}

Differences of physicochemical properties, microbial counts and fungal diversity between the tissues were evaluated using the Duncan's test. $P$-values below 0.05 were considered considered as being statistically significant. 
TABLE 1 | Physiochemical characterization of bacon tissues.

\begin{tabular}{|c|c|c|c|c|c|c|}
\hline Group & $\begin{array}{l}\text { Protein content (g } \\
\text { per } 100 \mathrm{~g})\end{array}$ & $\begin{array}{l}\text { Fat content (g per } \\
\qquad 100 \mathrm{~g})\end{array}$ & $\begin{array}{c}\text { Moisture content } \\
\text { (g per } 100 \mathrm{~g})\end{array}$ & $\begin{array}{l}\text { Salt content (g } \\
\text { per } 100 \mathrm{~g})\end{array}$ & $a_{w}$ & $\mathrm{pH}$ \\
\hline $\mathrm{M}_{\text {mean }}$ & $53.49 \pm 2.48^{a}$ & $5.54 \pm 0.23^{c}$ & $34.59 \pm 2.56^{a b}$ & $5.36 \pm 0.19^{a}$ & $0.84 \pm 0.02^{a}$ & $5.78 \pm 0.11^{a}$ \\
\hline$F_{\text {mean }}$ & $5.25 \pm 0.13^{c}$ & $84.06 \pm 1.80^{\mathrm{a}}$ & $8.22 \pm 0.16^{b}$ & $2.31 \pm 0.14^{b}$ & $0.77 \pm 0.02^{b}$ & $5.68 \pm 0.19^{a}$ \\
\hline$P_{\text {mean }}$ & $29.29 \pm 1.42^{b}$ & $24.57 \pm 1.48^{b}$ & $36.49 \pm 1.52^{\mathrm{a}}$ & $5.41 \pm 0.26^{a}$ & $0.84 \pm 0.04^{a}$ & $5.72 \pm 0.21^{a}$ \\
\hline
\end{tabular}

Letters indicate Duncan's pairwise differences among different tissues ( $p<0.05)$.

$M$, sample from the muscle tissue of bacon; $F$, sample from the adipose tissue of bacon; $P$, sample from pork skin of bacon.

\section{RESULTS}

\section{Physicochemical Analyses and Microbial Enumeration}

The $\mathrm{pH}$ of bacon ranged from 5.68 to 5.78; however, no significant difference $(\boldsymbol{P}>0.05)$ was found between the tissues (Table 1). Protein content, salt content, and $\mathrm{a}_{\mathrm{w}}$ of the adipose tissue were significantly lower than those of the other tissues $(\boldsymbol{P}<0.05)$. Fat content of the tissues ranged within 24.57-84.06 g per $100 \mathrm{~g}$, with the lowest and highest values from the muscle and adipose tissues, respectively. Moisture content of the adipose tissue was lowest $(P<0.05)$. The aerobic plate count on the PCA was lowest $(5.27 \pm 0.09 \log 10 \mathrm{CFU}$ per $\mathrm{g})$ in the muscle tissue (Table 2). There were significantly fewer xerophilic fungi for the muscle tissue on the DG18 (1.95 $\pm 0.08 \log 10 \mathrm{CFU}$ per $\mathrm{g})$ than that for the two other tissues $(\boldsymbol{P}<0.05)$. Additionally, molds and yeasts on the RB was lowest $(1.43 \pm 0.04 \log 10 \mathrm{CFU}$ per $\mathrm{g})$ in the muscle tissue (Table 2$)$. No significant difference $(\boldsymbol{P}>0.05)$ was found for aerobic plate count on the PCA, molds and yeasts on the RB, and xerophilic fungi on the DG18 between the adipose tissue and pork skin.

\section{Sequencing and Analysis of Alpha Diversity}

After quality filtering and chimera removal, 153,880 high quality sequencing reads (average $=8,548$ reads per sample) were obtained from 18 bacon samples, with the average read length of 211 bases for fungi. A total of 1,448 operational taxonomic units (OTUs) were generated from the high-quality sequences, with an average of 80 OTUs of individual samples (Table 3). The OTU richness was significantly lower in the muscle tissue (47 OTUs on average) than in the other two tissues (95 and 98 OTU richness for the adipose tissue and pork skin, respectively) $(\boldsymbol{P}<0.05)$. However, OTUs did not significantly differ between the adipose tissue and pork skin $(\boldsymbol{P}>0.05)$. Fungalcommunity

TABLE 2 | Microbial enumeration of the different bacon tissues.

\begin{tabular}{lccc}
\hline Group & $\begin{array}{c}\text { Aerobic plate count } \\
\log _{10} \text { CFU/g }\end{array}$ & $\begin{array}{c}\text { Xerophilic fungi } \\
\log _{\mathbf{1 0}} \text { CFU/g }\end{array}$ & $\begin{array}{c}\text { Molds and yeasts } \\
\log _{10} \text { CFU/g }\end{array}$ \\
\hline$M_{\text {mean }}$ & $5.27 \pm 0.09^{\mathrm{b}}$ & $1.95 \pm 0.08^{\mathrm{b}}$ & $1.43 \pm 0.04^{\mathrm{b}}$ \\
$\mathrm{F}_{\text {mean }}$ & $6.58 \pm 0.07^{\mathrm{a}}$ & $3.88 \pm 0.11^{\mathrm{a}}$ & $2.85 \pm 0.06^{\mathrm{a}}$ \\
$\mathrm{P}_{\text {mean }}$ & $6.77 \pm 0.09^{\mathrm{a}}$ & $3.90 \pm 0.08^{\mathrm{a}}$ & $2.91 \pm 0.05^{\mathrm{a}}$ \\
\hline
\end{tabular}

$M$, sample from muscle tissue of bacon; $F$, sample from adipose tissue of bacon; $P$, sample from pork skin of bacon. richness and diversity were assessed using three alpha-diversity metrics (Shannon, Chao1, and Good's coverage) (Table 3). The smallest and largest Shannon indexes were 1.51 and 3.37 for the muscle tissue and pork skin on average, respectively. The results indicated that fungal diversity was lowest in the muscle tissue. The smallest Chaol index was 93.1 for the muscle tissue on average.

\section{Fungal Communities in the Bacon Tissues}

There were six phyla detected in the tissues, two of which were dominant with relative abundances exceeding 1\%. Ascomycota was the most abundant phylum in all tissues, with a relative abundance range of $75.61-95.53 \%$ (Table 4). The relative abundance of Ascomycota in the muscle tissue was notable for exceeding 95\%. Basidiomycota was the second most predominant phylum in all tissues, accounting for only $3.13 \%$ of the sequences on average in the muscle tissue, but for 10.47 and $16.42 \%$ in the adipose tissue and pork skin, respectively. The relative abundances of the other four phyla (Glomeromycota, Mortierellomycota, Mucoromycota, and Rozellomycota) were below $1 \%$.

There were 91 genera found in the bacon tissues and the relative abundances of the dominant fungal genera are shown in Table 4. A total of nine dominant genera were obtained in all tissues, with relative abundances $>1 \%$. In the muscle tissue, five dominant genera (Debaryomyces, Aspergillus, Penicillium, Candida, and Malassezia) were observed, with relative abundance in the range of 2.15-67.67\%. Among them, Debaryomyces and Aspergillus were the first and second most abundant genera, representing $81.04 \%$ of the fungal population. In the adipose tissue, seven dominant genera (Debaryomyces, Aspergillus, Penicillium, Candida, Malassezia, Trichoderma, and

TABLE 3 | Reads, OTUs, Good's coverage, Chao1, and Shannon's indices for ITS rRNA sequencing of the bacon tissues.

\begin{tabular}{|c|c|c|c|c|c|c|c|c|c|c|}
\hline \multirow[t]{2}{*}{ Group } & \multicolumn{2}{|c|}{ Reads } & \multicolumn{2}{|c|}{ OTUs } & \multicolumn{2}{|c|}{ Good's coverage } & \multicolumn{2}{|c|}{ Chao1 } & \multicolumn{2}{|c|}{ Shannon } \\
\hline & Mean & SD & Mean & SD & Mean & SD & Mean & SD & Mean & SD \\
\hline M & 35923 & 1403 & 47 & $3^{b}$ & $96.58 \%$ & $0.1 \%$ & 93.1 & $3.5^{\mathrm{b}}$ & 1.51 & $0.34^{c}$ \\
\hline $\mathrm{F}$ & 37873 & 1190 & 95 & $6^{a b}$ & $95.19 \%$ & $0.4 \%$ & 160.7 & $5.2^{\mathrm{a}}$ & 2.94 & $0.35^{b}$ \\
\hline$P$ & 36962 & 1589 & 98 & $5^{a}$ & $94.98 \%$ & $0.5 \%$ & 153.9 & $6.1^{a b}$ & 3.37 & $0.39^{a}$ \\
\hline
\end{tabular}

Letters indicate Duncan's pairwise differences among different tissues $(p<0.05)$. $M$, sample from the muscle tissue of bacon; $F$, sample from the adipose tissue of bacon; $P$, sample from pork skin of bacon. 
TABLE 4 | Percentage of the main fungal phylum and genera in tissues.

\begin{tabular}{lccc}
\hline Fungi & \multicolumn{3}{c}{ Composition in tissues } \\
\cline { 2 - 4 } & $\mathbf{F}$ & $\mathbf{M}$ & $\mathbf{P}$ \\
& $\boldsymbol{n = 6}$ & $\boldsymbol{n = 6}$ & $\mathbf{n = 6}$ \\
\hline Phylum & & & \\
Ascomycota & $82.44 \%$ & $95.53 \%$ & $75.61 \%$ \\
Basidiomycota & $10.47 \%$ & $3.13 \%$ & $16.42 \%$ \\
Cercozoa & $0.05 \%$ & $0.02 \%$ & $0.17 \%$ \\
Glomeromycota & $0.04 \%$ & $0.01 \%$ & $0.04 \%$ \\
Mucoromycota & $0.01 \%$ & $0.00 \%$ & $0.01 \%$ \\
Rozellomycota & $0.01 \%$ & $0.00 \%$ & $0.01 \%$ \\
Mortierellomycota & $0.00 \%$ & $0.01 \%$ & $0.01 \%$ \\
Genus & & & \\
Debaryomyces & $30.09 \%$ & $67.67 \%$ & $15.08 \%$ \\
Aspergillus & $14.04 \%$ & $13.37 \%$ & $9.38 \%$ \\
Candida & $8.29 \%$ & $3.55 \%$ & $16.30 \%$ \\
Malassezia & $7.59 \%$ & $2.15 \%$ & $12.67 \%$ \\
Penicillium & $8.91 \%$ & $4.13 \%$ & $4.89 \%$ \\
Trichoderma & $6.81 \%$ & $0.50 \%$ & $1.62 \%$ \\
Tausonia & $1.14 \%$ & $0.56 \%$ & $1.73 \%$ \\
Fusicolla & $0.53 \%$ & $0.73 \%$ & $1.68 \%$ \\
Acremonium & $0.92 \%$ & $0.56 \%$ & $1.37 \%$ \\
\hline M. & & & \\
\hline
\end{tabular}

$M$, sample from the muscle tissue of bacon; $F$, sample from the adipose tissue of bacon; P, sample from pork skin of bacon.

Tausonia) occurred, with relative abundance of $30.09,14.07,8.91$, $8.29,7.59,6.81$, and $1.14 \%$, respectively. In the pork skin, nine fungal genera (Candida, Debaryomyces, Malassezia, Aspergillus, Penicillium, Tausonia, Fusicolla, Trichoderma, and Acremonium) were dominant, with relative abundance of 16.30, 15.08, 12.67, $9.38,4.89,1.73,1.68,1.62$, and $1.37 \%$, respectively. Additionally, a total of 82 non-dominant genera (relative abundance $<1 \%$ ) were identified in the tissues.

\section{Comparison of Fungal Communities}

A Venn diagram with unique and shared OTUs of the fungal communities was constructed to show the differences and similarities among the tissues (Figure 2). A total of 339 OTUs were observed, and 98 were common to all tissues. The numbers of OTUs unique to individual tissues were 14, 67, and 65 for the muscle tissue, the adipose tissue, and pork skin, respectively. The pork skin and the adipose tissue shared more OTUs (168 or $49.6 \%$ of the total) than either did with the muscle tissue.

The LEfSe analysis was applied to identify the potential distinguishable taxa among different tissues (Figures $3 \mathbf{A}, \mathbf{B}$ ). A cladogram showed 31 significantly different taxa between the tissues: two phyla, two classes, seven orders, eleven families, and nine genera (LDA score $\geq 3.0$ and $\boldsymbol{P} \leq 0.05$; Figure $3 \mathrm{~B}$ ). In the muscle tissue, five taxa were enriched including one phylum (Ascomycota), one class (Saccharomycetes), one order (Saccharomycetales), one family (Debaryomycetaceae), and one genus (Debaryomyces), and all of them had an LDA value higher than 5.0 (Figure 3A). In the adipose tissue, the fungal groups enriched were one order (Trichosphaeriales), three families (Hypocreaceae, Meruliaceae, and Trichosphaeriaceae) and three

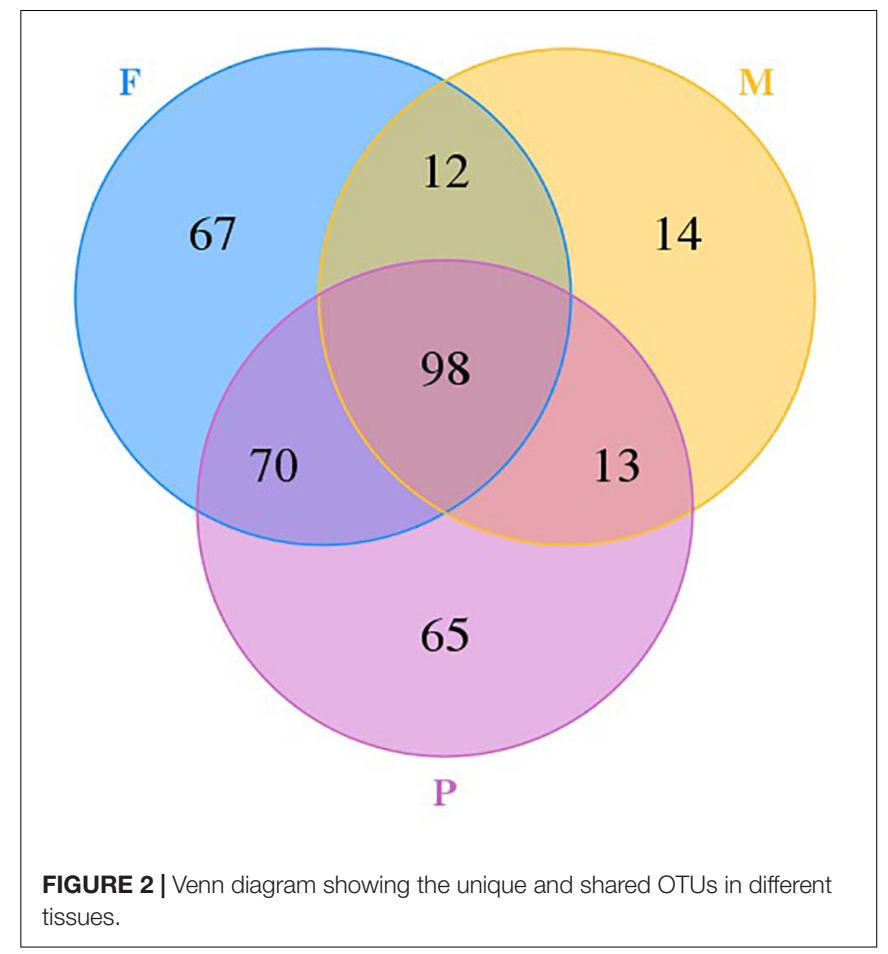

genera (Bjerkandera, Nigrospora, and Trichoderma), both with LDA values higher than 4.0 (Figure 3A).

In the pork skin, 19 significantly different taxa were found, which included one phylum (Basidiomycota), one class (Dothideomycetes), five orders (Capnodiales, Microascales, Onygenales, Pleosporales, and Sordariales), seven families (Arachnomycetaceae, Cephalothecaceae, Chaetomiaceae, Cystofilobasidiaceae, Leptosphaeriaceae, Microascaceae, and Onygenales fam Incertae sedis), and five genera (Arachnomyces, Cystofilobasidium, Diploospora, Microascus, Phialemonium). Among them, 8 significantly different taxa had LDA values exceeding 4.0 (Figure 3A).

Beta diversity results of NMDS based on Jaccard distance indicated the data distribution of bacon tissues (Figure 4). Fungal communities in the adipose tissue and pork skin were more similar and located closer to each other, while the muscle tissue clearly separated. Adonis/PERMANOVA analysis performed on the tissues showed that $P=0.011(P<0.05)$, indicating that the tissue state of bacon was a crucial factor influencing the fungal composition of the different tissues.

\section{Interactions of Fungi in Bacon Tissues}

In this study, the SparCC algorithm was used to calculate the relationship between genera identified in bacon and visualized as a network ( $\mathrm{v}$ 3.7.1). The network for fungal communities in the pork skin consisted of 50 nodes and 45 edges (Figure 5). Our results suggested that the network was cooperative, and the ratio of cooperative and non-cooperative interactions was 31:14. No hub genera ( $\geq 5$ edges per node) was found in the network. Candida, the most dominant genus in the pork skin, had a positive relationship with Fusicolla. All effects related 


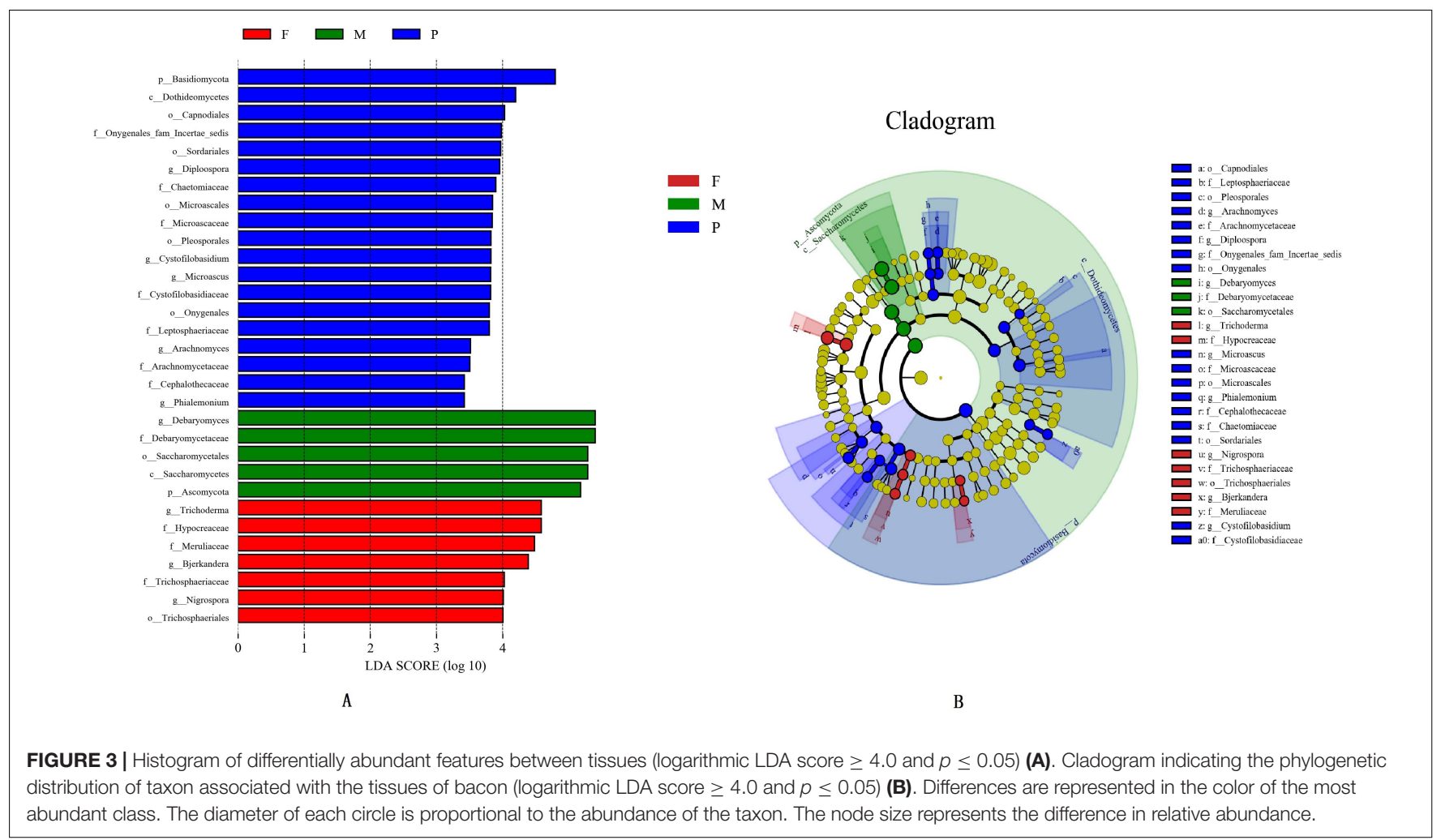

to Debaryomyces were positive, including two other genera: Fusicolla and Sarocladium. Malassezia had a negative relationship with Torula and Dichotomopilus, but had a positive relationship with two other genera: Naganishia and Knufia.

The network for the fungal communities in the adipose tissue consisted of 50 nodes and 46 edges (Figure 6). Results suggested that the network was non-cooperative, and the ratio of cooperative and non-cooperative interactions was 21:23. Scopulariopsis and Botryotrichum were the first and second hub genera in the network. Scopulariopsis had a negative relationship with seven genera (Diploospora, Periconia, Thermomyces, Candida, Lecanicillium, Cosmospora, and Phialemonium). Botryotrichum had a negative relationship with Toxicocladosporium, Gamsia, and Simplicillium, but a positive relationship with Acaulium and Lecanicillium.

The network for the fungal communities in the muscle tissue consisted of 39 nodes and 43 edges (Figure 7). Results suggested that the network was cooperative, and the ratio of cooperative and non-cooperative interactions was 26:17. Three hub genera (Zasmidium, Fusicolla and Cryptococcus) were found in the network. All effects related to Zasmidium were positive, including five other genera: Clonostachys, Fusicolla, Chyrsosporium, Cryptococcus, and Colletotrichum. Fusicolla had a negative relationship with Malassezia and Debaryomyces, but a positive relationship with Zasmidium, Clonostachys, and Tausonia. Cryptococcus had a negative relationship with Clonostachys and Acremonium, but a positive relationship with Zasmidium, Peniophora, and Cystofilobasidium.

\section{DISCUSSION}

\section{Fungal Communities in Sichuan Pork Bacon Tissues}

Pork bacon, a traditional meat product, has long been popular in the south of China (Yi et al., 2016). During the production of traditional pork bacon, raw meat is processed under exposed conditions; hence, a variety of microorganisms may be involved in this specific food ecosystem. In the present study, a total of 6 fungal phyla were detected in the bacon tissues. Among them, Ascomycota and Basidiomycota were the first and second most abundant phyla in the bacon tissues. These phyla were previously detected in fresh and chilled pork (Yang et al., 2017), traditional fermented fish (Osimani et al., 2019), and dry aged beef (Ryu et al., 2018). There were 91 genera tested in the bacon tissues, including nine dominant genera and 82 non-dominant genera. Among them, five dominant genera (Aspergillus, Candida, Debaryomyces, Malassezia, and Penicillium) were shared by all bacon tissues. Aspergillus was also detected with higher abundance in fresh and chilled pork (Yang et al., 2017). Debaryomyces and Candida were also present in the traditional Icelandic fermented fish (Osimani et al., 2019), dry aged beef (Ryu et al., 2018), traditional llama meat sausages (Mendoza et al., 2014), and Norwegian dry-cured meat products (Asefa et al., 2009b), and Portuguese cacholeira blood sausage (Belleggia et al., 2020). Penicillium was also present in Spanish fermented meat sausage (Lopez-Diaz et al., 2001), dry aged beef (Ryu et al., 2018), and dry-cured teruel ham (Cavus et al., 2018). 


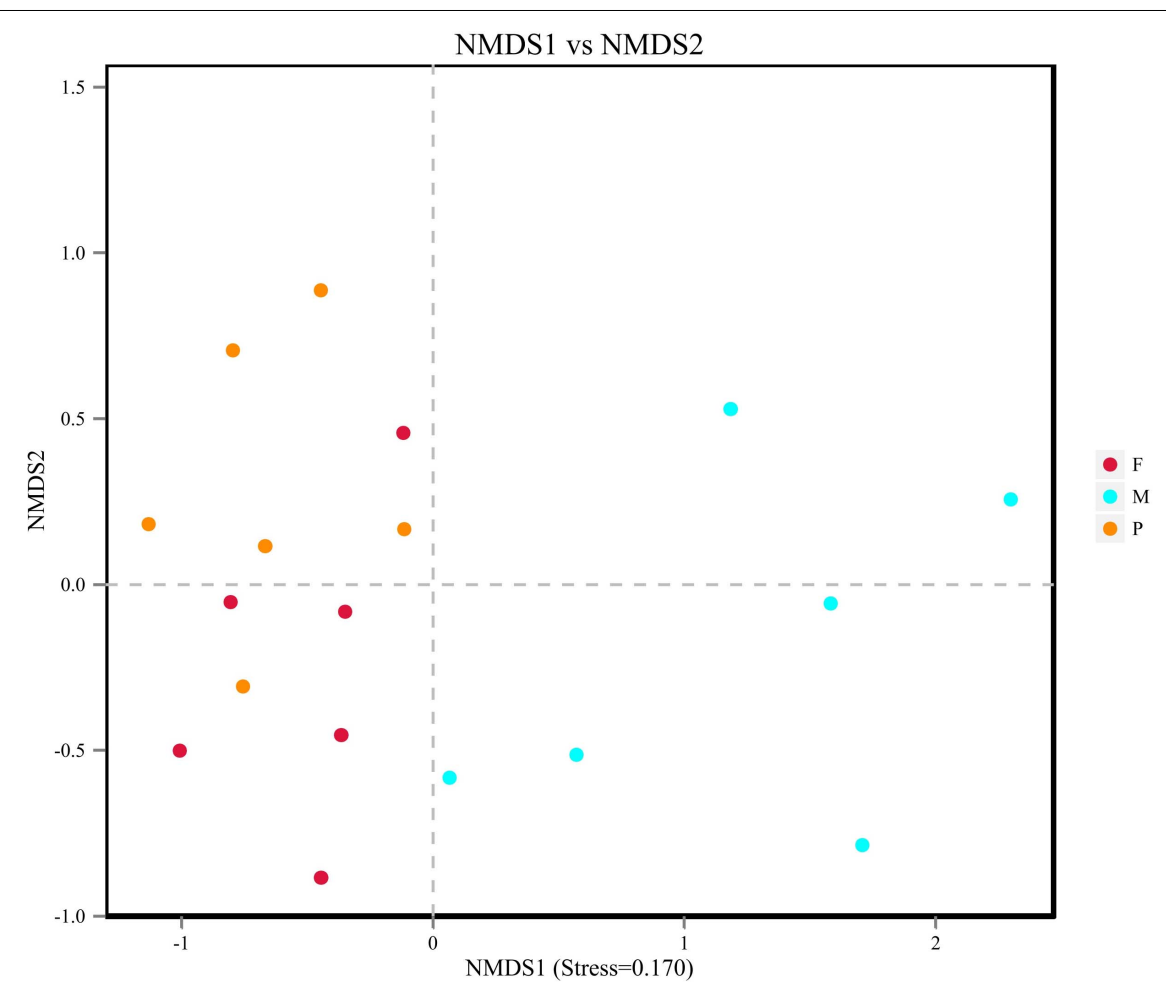

FIGURE 4 | Non-metric dimensional scaling (NMDS) plot showing the association between fungal communities in bacon.

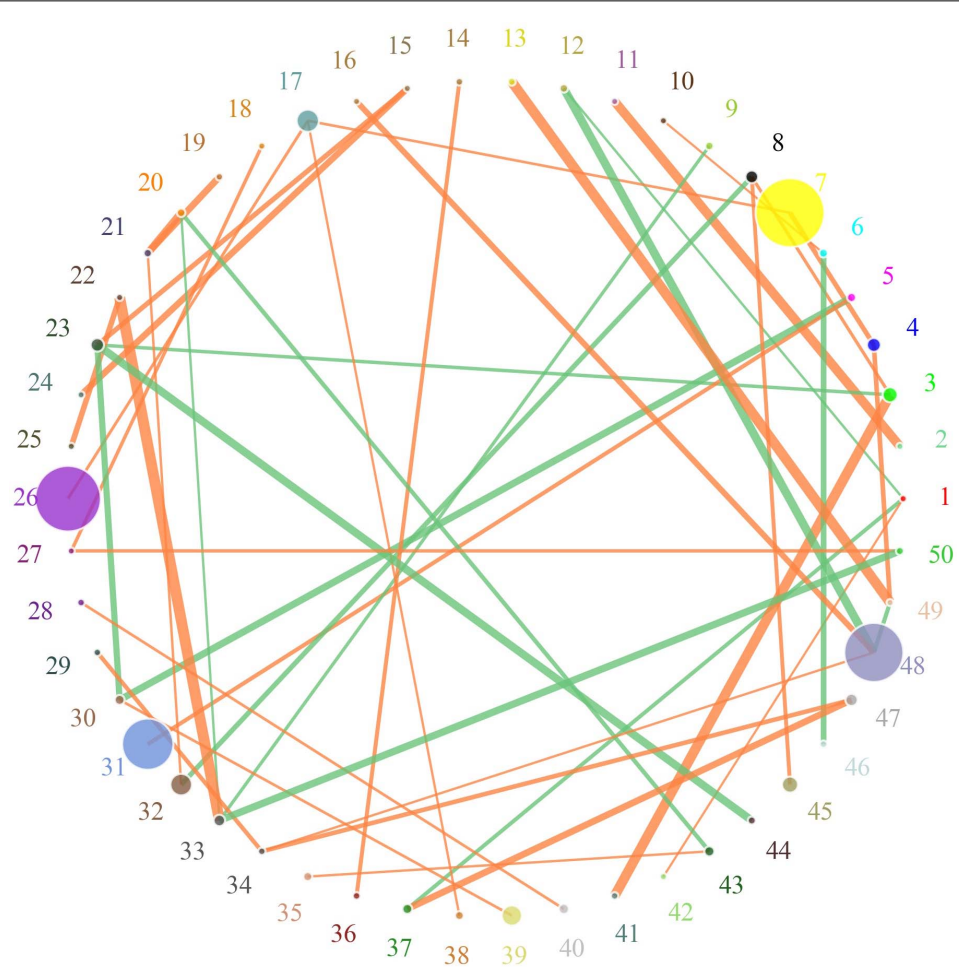

1: Scopulariopsis 2: Trichothecium 3: Fusarium

4: Sarocladium 5: Mrakia 6: Stachybotrys 7: Debaryomyces 8: Arachnomyces 9: Pyrenochaeta

10: Graphium 11: Hyphoderma 12: Torula

13: Subulicystidium 14: Oidiodendron 15: Thermomyces 16: Naganishia 17: Fusicolla

18: Kazachstania 19: Wickerhamomy 20: Myrmecridium 21: Nigrospora 22: Chaetomium 23: Cladosporium 24: Mrakiella 25: Tilletiopsis
26: Candida 27: Mycosphaerella 28: Neodevriesia 29: Aureobasidium 030: Talaromyces 31: Aspergillus 32: Tausonia 33: Cephalotrichum 34: Knufia 35: Thermoascus 36: Simplicillium 37: Entyloma

338: Sterigmatomyces 339: Acremonium 40: Melanospora 41: Xerochrysium 42: Wallrothiella

43: Zasmidium 44: Toxicocladosporium 45: Microascus 46: Ustilaginoidea 47: Alternaria 48: Malassezia 49: Dichotomopilus 50: Trametes

FIGURE 5 | Networks of fungal interaction in the pork skin. Circle is on behalf of the genus, size of the circle represents the abundance. Lines represent the correlation between the two species, line thickness to represent the strength of the correlation (the larger the correlation coefficient, the thicker the line), the color of the line: orange represents the positive correlation, green represents the negative correlation. 


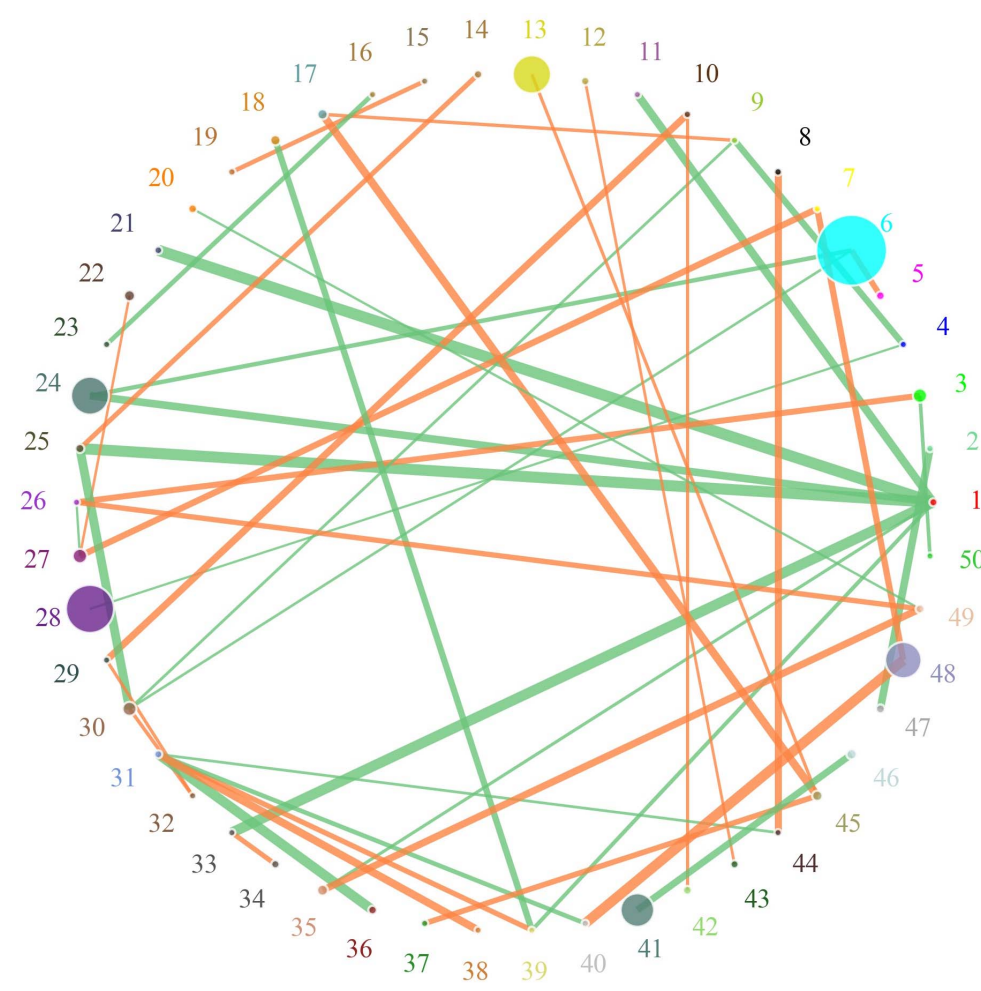

\begin{tabular}{|c|c|}
\hline 1: Scopulariopsis & 26: Anomoloma \\
\hline 2: Antrodia & 27: Talaromyces \\
\hline 3: Sarocladium & 28: Aspergillus \\
\hline 4: Tilletiopsis & 29: Rosellinia \\
\hline 5: Stachybotrys & 30: Acremonium \\
\hline 6: Debaryomyces & 31: Botryotrichum \\
\hline 7: Comoclathris & 32: Cordyceps \\
\hline 8: Sterigmatomyces & 33: Periconia \\
\hline 9: Graphium & 34: Peniophora \\
\hline 10: Phialosimplex & 35: Cosmospora \\
\hline 11: Thermomyces & 36: Simplicillium \\
\hline 12: Bjerkandera & 37: Colletotrichum \\
\hline 13: Penicillium & 38: Acaulium \\
\hline 14: Cryptococcus & 39: Lecanicillium \\
\hline 15: Kazachstania & 40: Gamsia \\
\hline 16: Wickerhamomyces & sO 41: Trichoderma \\
\hline 17: Leucosporidium & 42: Xerochrysium \\
\hline 18: Nigrospora & 43: Wallrothiella \\
\hline 19: Chaetomium & 44: Toxicocladosporium \\
\hline 20: Rhodotorula & 45: Microascus \\
\hline 21: Diploospora & 46: Ustilaginoidea \\
\hline 22: Cladosporium & 47: Alternaria \\
\hline 23: Mrakia & 48: Malassezia \\
\hline 24: Candida & 49: Cystofilobasidium \\
\hline 25: Phialemonium & 50: Paracremonium \\
\hline
\end{tabular}

FIGURE 6 | Networks of fungal interaction in the adipose tissue. Circle is on behalf of the genus, size of the circle represents the abundance. Lines represent the correlation between the two species, line thickness to represent the strength of the correlation (the larger the correlation coefficient, the thicker the line), the color of the line: orange represents the positive correlation, green represents the negative correlation.

Previous studies have shown that climate, geography, and processing technology had affected the microbial communities in the meat products (Doulgeraki et al., 2012; Yi et al., 2016; Yang et al., 2017; Wang et al., 2018). Because bacon is naturally processed without the use of starter cultures, these fungi may emerge from raw materials or the processing environment. Doulgeraki et al. (2012) have found that raw meat was the main source of microorganisms in bacon preparation. In the process of producing bacon, cured meat is generally hung, smoked and ripened under exposed conditions for a few months; therefore, a variety of endogenous and exogenous microorganisms may be involved. In this study, the climate of Dazhou belongs to the sub-tropical moist monsoon type, which is suitable for the growth of molds and has a great influence on the microbial population in the bacon. Similar results were found in the process of manufacturing dry fermented sausage and other meat products (Scaramuzza et al., 2015; Bernardi et al., 2019; Parussolo et al., 2019). In the present study, Acremonium, Candida, Fusicolla, Penicillium, Tausonia, and Trichoderma were detected in all the bacon tissues, which were previous found in decayed wood (Kim et al., 2006; Guo et al., 2012; Rahmawati et al., 2020). During the processing of Sichuan pork bacon, local producers often use some old wooden utensils, such as chopping board. In addition, bacon is generally ripened in an old house, where the doors, windows, and beams are made of wood. Hence, microorganisms associated with decayed wood in the environment could be involved.

\section{Effect of Physicochemical Properties of Bacon Tissue on Fungal Communities}

We found that the microorganisms in different parts of bacon exhibited a large degree of biodiversity. LEfSe analysis showed 31 significantly different taxa among the tissues: two phyla, two classes, seven orders, eleven families, and nine genera (Figures 3A,B). The relative abundance of two dominant phyla (Ascomycota and Basidiomycota) significantly differed among the three groups as also did the abundances of nine dominant genera (Table 4). In the present study, the production environment and processing technology of the bacon collected were roughly the same. However, pork meat used in bacon production consists of skin, fat, and lean meat. There are significant differences in the nutritional composition and tissue structure of these tissues (Henry et al., 1963), which may affect the attached microorganisms. As we all known, the growth of microorganisms are greatly affected by the nutritional and environmental factors (Madigan et al., 2011). During the processing and ripening of bacon, different pork tissues serve as selective medium for the growth and reproduction of microorganisms. Different organisms have different preferences for different nutrients and environmental conditions. Therefore, different kinds of microorganisms will be enriched on the surface of different parts of bacon. Similar results were found in the previous study (Greer et al., 1995). Redundancy analysis showed that three dominant fungal genera in bacon (Aspergillus, 


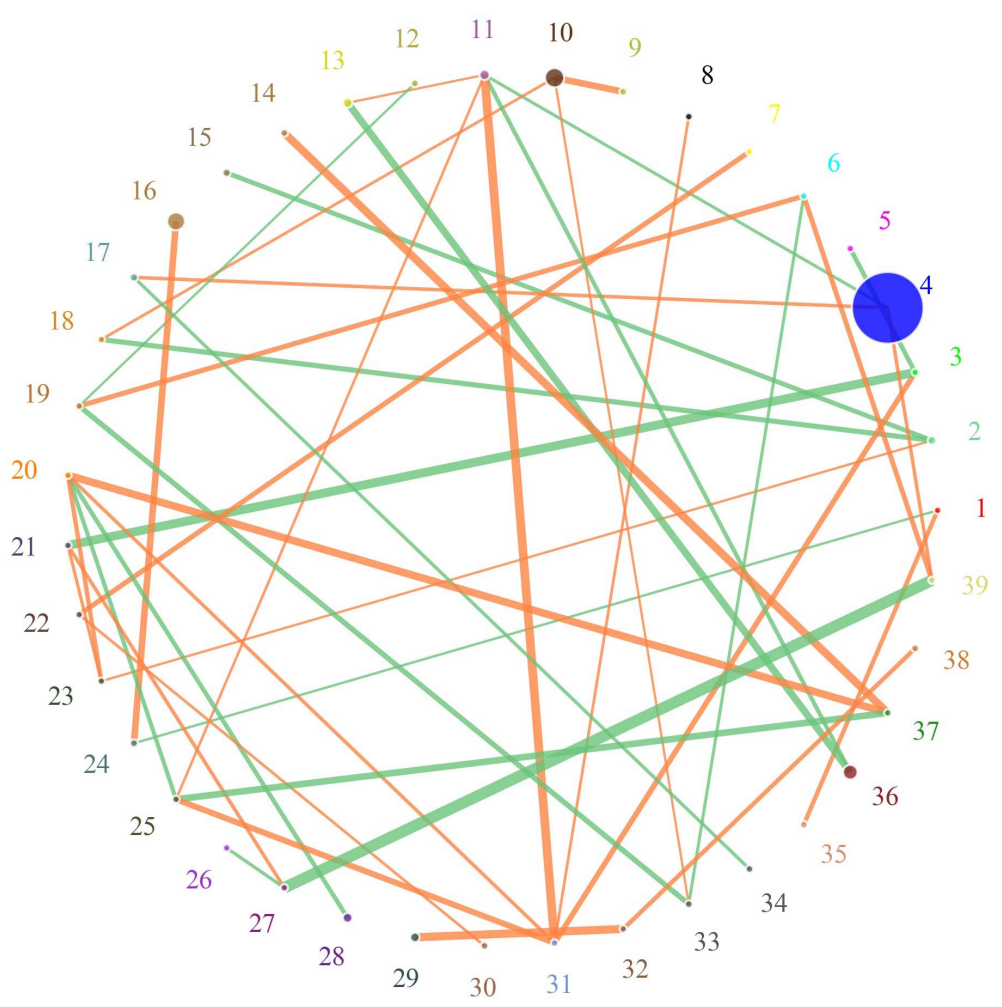

\begin{tabular}{|c|c|}
\hline 1: Scopulariopsis & 21: Thermoascus \\
\hline 2: Fusarium & 22: Geosmithia \\
\hline 3: Chrysosporium & 23: Peniophora \\
\hline 4: Debaryomyces & 24: Cosmospora \\
\hline 5: Sterigmatomyces & 25: Clonostachys \\
\hline 6: Stachylidium & 26: Entyloma \\
\hline 7: Setophoma & 27: Cyphellophora \\
\hline 8: Colletotrichum & 28: Acremonium \\
\hline 9: Nigrospora & 29: Trichoderma \\
\hline 10: Penicillium & 30: Xerochrysium \\
\hline 11: Fusicolla & 31: Zasmidium \\
\hline 12: Leucosporidium & 32: Exophiala \\
\hline 13: Tausonia & 33: Microascus \\
\hline 14: Diploospora & 34: Ustilaginoidea \\
\hline 15: Cladosporium & 35: Alternaria \\
\hline 16: Candida & 36: Malassezia \\
\hline 17: Talaromyces & 37: Cystofilobasidium \\
\hline 18: Calcarisporium & 38: Trametes \\
\hline 19: Botryotrichum & 39: Pseudopithomyces \\
\hline 20: Cryptococcus & \\
\hline
\end{tabular}

FIGURE 7 | Networks of fungal interaction in the muscle tissue. Circle is on behalf of the genus, size of the circle represents the abundance. Lines represent the correlation between the two species, line thickness to represent the strength of the correlation (the larger the correlation coefficient, the thicker the line), the color of the line: orange represents the positive correlation, green represents the negative correlation.

Penicillium, and Trichoderma) were positively correlated with fat content and $\mathrm{pH}$ (Figure 8). Debaryomyces showed positive correlation to protein content and $\mathrm{pH}$ (Figure 8). Candida, Fusicolla, Malassezia, and Tausonia were positively correlated with $\mathrm{a}_{\mathrm{w}}$, indicating that their growth was profoundly influenced by salt content and moisture content. Previous studies showed that Penicillium, Trichoderma, and Aspergillus were the most prevalent fungi on fresh meat samples and can produce lipase (Abdel-Sater et al., 2017). Debaryomyces hansenii, can produce protease which is possible to use in meat production (Tomás et al., 2008). The growth characteristics of these fungi in this study are not yet clear. Therefore, future studies should isolate and grow these fungi to investigate their growth characteristics.

\section{Characteristics and Interaction of Fungi in Meat Products}

Various microbes inhabit traditional foods, and do not exist in isolation (Faust and Raes, 2012; Zhu et al., 2018). The effect of mutual interaction between the co-inhabiting microbes in food ecology is known to play a key part in quality and flavor of food products. Debaryomyces and Candida are the most frequently isolated yeasts from meat products (Fleet, 2011). The best-known species of this genus, Debaryomyces hansenii showed higher lipolytic activity levels and can contribute to flavor and texture development of meat products (Mendoza et al., 2014). This species can grow under high salt concentrations and is considered an extremophilic organism (Haque et al., 2015). In other reports, Debaryomyces hansenii can reduced Ochratoxin A content in meat portions significantly when co-inoculated with Penicillium nordicum (Simoncini et al., 2014). Candida, a member of the class Saccharomycetes, is a heterogeneous genus that comprises pathogenic species. However, some species of Candida play important roles in enhancing the taste and quality of meat products (Martín et al., 2006; Simoncini et al., 2007). Candida zeylanoides can inhibit the growth of Penicillium nordicum in dry-cured ham and dry fermented sausage (Meftah et al., 2020). Aspergillus, the most common genus of mold found in the environment, includes approximately 185 species (Moy et al., 2012). Some species of Aspergillus, such as Aspergillus ruber, Aspergillus niveoglaucum, and Aspergillus repens, have a higher proteolytic and lipolytic activity and contribute to the development of the characteristic flavor of the meat product (Alapont et al., 2015). However, some other species of this genus are able to synthesize mycotoxins in a meat substrate when grown under favorable conditions. For example, Aspergillus flavus and Aspergillus parasiticus commonly found in the meat products can produce aflatoxin B1 (Martin et al., 2004; Cavus et al., 2018). Penicillium, a member of the order Eurotiales, is comparable to Aspergillus (Visagie et al., 2014). Most species of Pencillium fungi are opportunistic and can 


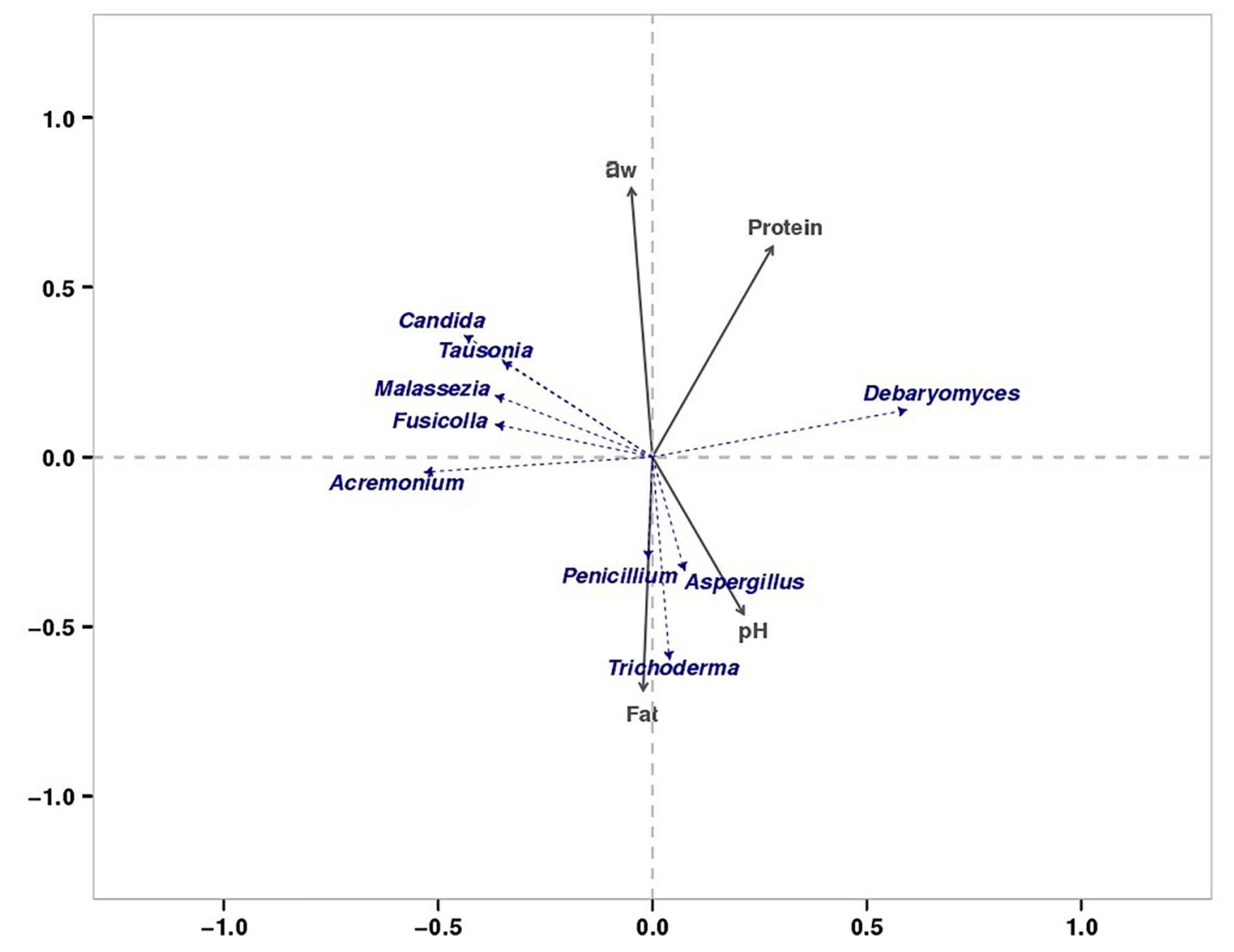

FIGURE 8 | RDA of dominant fungi and major physiochemical properties.

cause fungal spoilage in fruits and vegetables (Tournas, 2005). Some species of Penicillium can produce fungal toxins under certain conditions (Eriksen et al., 2012). However, Penicillium is not merely a harmful fungus (Perrone and Susca, 2017). Numerous species of this genus produce extracellular enzymes such as glucoamylase, lipase, pectinase, and alpha-amylase, which may affect product quality (Chellegatti et al., 2000; Balkan and Ertan, 2005; Bancerz et al., 2006; Magistà et al., 2017). Penicillium roquefortii and Penicillium camambertii are two common species used to produce cheese (Toelstede and Hofmann, 2009; Fairclough et al., 2011). Penicillium chrysogenum can produce glucose oxidase, which can help to prevent fungal decay and be used as a preservative (Konishi et al., 2013; Garrigues et al., 2018). Malassezia, a yeast-like fungus, which lack the ability to synthesize medium-chain and long-chain fatty acids (Roberta et al., 2020). It is generally found on normal skin, which causes opportunistic infections. Some species of Malassezia were also detected in some refrigerators (Ye et al., 2019). In the present study, the exact function of these fungi was not determined. Therefore, future studies should isolate these fungi and investigate their interactions by co-culture or other methods.

\section{CONCLUSION}

In this study, five dominant genera (Aspergillus, Candida, Debaryomyces, Malassezia, and Penicillium) were shared by all bacon tissues, and a total of 31 operational taxonomic units at different levels significantly differed between different tissues. The results also showed that fungal communities in different bacon tissue were significantly different. Results of redundancy analysis and network analysis indicated that physicochemical properties of bacon tissue were a crucial factor influencing the fungal diversity and communities of homemade traditional Sichuan bacon. This study will improve our understanding of the fungal diversity and communities in traditional pork bacon. Further investigations are required to identify these isolate from the product and to reveal the interaction between spoilage and microbes.

\section{DATA AVAILABILITY STATEMENT}

The datasets presented in this study can be found in online repositories. The names of the repository/repositories and 
accession number(s) can be found below: https://www.ncbi.nlm. nih.gov/, PRJNA610642.

\section{AUTHOR CONTRIBUTIONS}

HQ is co-first author. MZ, HQ, and WZ contributed conception and design of the study. ZZ, PW, and YZ performed the statistical analysis. $M Z$ and HQ wrote the first draft of the manuscript. All authors

\section{REFERENCES}

Abdel-Sater, M. A., Al-Sharjab, F. A., and Al-Ashwal, E. S. (2017). Mycological and enzymatic studies on fresh beef meat sold in Taiz City, Yemen. Eur. J. Biol Res. 7, 337-347. doi: 10.5281/zenodo.1037238

Alapont, C., Martinez-Culebras, P. V., and Lopez-Mendoza, M. C. (2015). Determination of lipolytic and proteolytic activities of mycoflora isolated from dry-cured teruel ham. J. Food Sci. Tech. Mys. 52, 5250-5256. doi: 10.1007/ s13197-014-1582-5

Asefa, D. T., Moretro, T., Gjerde, R. O., Langsrud, S., Kure, C. F., Sidhu, M. S., et al. (2009b). Yeast diversity and dynamics in the production processes of Norwegian dry-cured meat products. Int. J. Food Microbiol. 133, 135-140. doi: 10.1016/j.ijfoodmicro.2009.05.011

Balkan, B., and Ertan, F. (2005). Production and properties of alpha-amylase from Penicillium chrysogenum and its application in starch hydrolysis. Prep. Biochem. Biotech. 35, 169-178. doi: 10.1081/PB-200054740

Bancerz, R., Ginalska, G., Fiedurek, J., and Gromada, A. (2006). Cultivation conditions and properties of extracellular crude lipase from the psychrotrophic fungus Penicillium chrysogenum 9'. J. Ind. Microbiol. Biot. 32, 253-260. doi: 10.1007/s10295-005-0235-0

Belleggia, L., Ferrocino, I., Reale, A., Boscaino, F., Renzo, T. D., Corvaglia, M. R., et al. (2020). Portuguese cacholeira blood sausage: a first taste of its microbiota and volatile organic compounds. Food Re. Int. 136:109567. doi: 10.1016/j. foodres.2020.109567

Bernardi, A. O., Garcia, M. V., and Copetti, M. V. (2019). Food industry spoilage fungi control through facility sanitization. Curr. Opin. Food Sci. 29, 28-34. doi: 10.1016/j.cofs.2019.07.006

Caporaso, J. G., Kuczynski, J., Stombaugh, J., Bittinger, K., Bushman, F. D., Costello, E. K., et al. (2010). QIIME allows analysis of high-throughput community sequencing data. Nat. Methods 7, 335-336. doi: 10.1038/nmeth.f. 303

Cavus, S., Tornuk, F., Sarioglu, K., and Yetim, H. (2018). Determination of mold contamination and aflatoxin levels of the meat products/ingredients collected from Turkey market. J. Food Safety 38:e12494. doi: 10.1111/jfs.12494

Chellegatti, M. A., Kawano, C. Y., Said, S., and Fonseca, M. J. (2000). Sequential synthesis and secretion of pectinases by Penicillium frequentans. J. Basic Microb. 40, 319-326.

Doulgeraki, A. I., Ercolini, D., Villani, F., and Nychas, G. J. E. (2012). Spoilage microbiota associated to the storage of raw meat in different conditions. Int. J. Food Microbiol. 157, 130-141. doi: 10.1016/j.ijfoodmicro.2012.05.020

Ellis, M., Smith, W. C., Henderson, R., Whittemore, C. T., and Laird, R. (1983). Comparative performance and body composition of control and selection line large white pigs 2. feeding to appetite for a fixed time. Ani. Sci. 36, 407-413. doi: 10.1017/S000335610001045X

Eriksen, G. S., Rundberget, T., Wigestrand, M. B., Fonnum, F., Bernhoft, A., and Moldes-Anaya, A. (2012). Poisoning by penicillium toxins-Clinical and brain receptor effects. Toxicol. Lett. 211, 58-59. doi: 10.1016/j.toxlet.2012.03.231

Fairclough, A. C., Cliffe, D. E., and Knapper, S. (2011). Factors affecting Penicillium roquefortii (Penicillium glaucum) in internally mould ripened cheeses: implications for pre-packed blue cheeses. Int. J. Food Sci.Tech. 46, 1586-1590. doi: 10.1111/j.1365-2621.2011.02658.x

Faust, K., and Raes, J. (2012). Microbial interactions: from networks to models. Nat. Rev. Microbiol. 10, 538-550. doi: 10.1038/nrmicro2832 contributed to manuscript revision, read, and approved the submitted version.

\section{FUNDING}

This work was supported by the National Natural Science Fund of China (31760466, 31960486, and 21864002) and the Natural Science Fund of Gansu Province (20JR10RA524) for financial support.

Fleet, G. H. (2011). "Chapter 5 - yeast spoilage of foods and beverages", in The Yeasts, 5th Edn, eds C. P. Kurtzman, J. W. Fell, and T. Boekhout (London: Elsevier), 53-63.

Friedman, J., and Alm, E. J. (2012). Inferring correlation networks from genomic survey data. PLoS. Comput. Biol. 8:e1002687. doi: 10.1371/journal.pcbi.1002687

Garrigues, S., Gandía Gómez, M., Castillo, L., Coca, M., Marx, F., Marcos López, J. F., et al. (2018). Three antifungal proteins from Penicillium expansum: different patterns of production and antifungal activity. Front. Microbiol. 9:2370. doi: 10.3389/fmicb.2018.02370

Greer, G. G., Gill, C. O., and Dilts, B. D. (1995). Predicting the aerobic growth of Yersinia enterocolitica on pork fat and muscle tissues. Food Microbiol. 12, 463-469. doi: 10.1006/fmic.1995.0062

Guo, X., Huang, F., Zhang, H., Zhang, C., Hu, H., and Chen, W. (2016). Classification of traditional Chinese pork bacon based on physicochemical properties and chemometric techniques. Meat Sci. 117, 182-186. doi: 10.1016/j. meatsci.2016.02.008

Guo, X. Y., Zhu, H. K., and Bai, F. Y. (2012). Candida cellulosicola sp. nov., a xyloseutilizing anamorphic yeast from rotten wood. Int. J. Sustainable Econ. Manag. 62, 242-245. doi: 10.1099/ijs.0.031351-0

Haque, M. A., Seo, W. T., Hwang, C. E., Lee, H. Y., Ahn, M. J., and Cho, K. M. (2015). Culture-independent analysis of yeast diversity in Korean traditional fermented soybean foods (doenjang and kanjang) based on 26S rRNA sequence. J. Korean Soc. Appl. Biol. Chem. 58, 377-385. doi: 10.1007/s13765-0150030-1

Henry, W. E., Bratzler, L. J., and Luecke, R. W. (1963). Physical and chemical relationships of pork carcasses. J. Ani. Sci. 22, 613-616. doi: 10.2527/jas1963. 223613x

Huang, P., Shao, X. F., Zhu, M. M., Xu, B. C., Chen, C. G., and Li, P. J. (2020). Sucrose enhances colour formation in dry sausages by up-regulating gene expression of nitric oxide synthase in Staphylococcus vitulinus. Int. J. Food Microbiol. 315:108419. doi: 10.1016/j.ijfoodmicro.2019.108419

Kim, G. H., Son, D. S., and Kim, J. J. (2006). Fungi colonizing Douglas-fir in cooling towers: identification and their decay capabilities. Wood Fiber Sci. 37, 638-642.

Koljalg, U., Nilsson, R. H., Abarenkov, K., Tedersoo, L., Taylor, A. F. S., Bahram, M., et al. (2013). Towards a unified paradigm for sequence-based identification of fungi. Mol. Ecol. 22, 5271-5277. doi: 10.1111/mec.12481

Konishi, T., Aoshima, T., Mizuhashi, F., Choi, S. S. H., and Roberts, A. (2013). Safety evaluation of glucose oxidase from Penicillium chrysogenum. Regul. Toxicol. Pharm. 66, 13-23. doi: 10.1016/j.yrtph.2013.02.012

Li, X., Li, C., Ye, H., Wang, Z., Wu, X., Han, Y., et al. (2019). Changes in the microbial communities in vacuum-packaged smoked bacon during storage. Food Microbiol. 77, 26-37. doi: 10.1016/j.fm.2018.08.007

Lopez-Diaz, T.-M., Santos, J.-A., Garcia-Lopez, M.-L., and Otero, A. (2001). Surface mycoflora of a Spanish fermented meat sausage and toxigenicity of Penicillium isolates. Int. J. Food Microbiol. 68, 69-74. doi: 10.1016/S01681605(01)00472-X

Lozupone, C. A., Hamady, M., Kelley, S. T., and Knight, R. (2007). Quantitative and qualitative diversity measures lead to different insights into factors that structuremicrobial communities. Appl. Environ. Microbiol. 73, 1576-1585. doi: 10.1128/AEM.01996-06

Luo, Q., Zhu, Y., Zhang, Z., Cao, Y., and Zhang, W. (2020). Variations in fungal community and diversity in Doushen with different flavors. Front. Microbiol. 11:447. doi: 10.3389/fmicb.2020.00447 
Madigan, T. M., Martinko, J. M., Stahl, D. A., and Clark, D. P. (2011). Brock Biology of Microorganisms 13th Edn. London: Pearson Education, 118-132.

Magistà, D., Susca, A., Ferrara, M., Logrieco, A. F., and Perrone, G. (2017). Penicillium species: crossroad between quality and safety of cured meat production. Curr. Opin. Food Sci. 17, 36-40. doi: 10.1016/j.cofs.2017.09.007

Magoc, T., and Salzberg, S. L. (2011). FLASH: fast length adjustment of short reads to improve genome assemblies. Bioinformatics 27, 2957-2963. doi: 10.1093/ bioinformatics/btr507

Martín, A., Córdoba, J. J., Aranda, E., Córdoba, M. G., and Asensio, M. A. (2006). Contribution of a selected fungal population to the volatile compounds on drycured ham. Int. J. Food Microbiol. 110, 8-18. doi: 10.1016/j.ijfoodmicro.2006. 01.031

Martin, A., Jurado, M., Rodriguez, M., Nunez, F., and Cordoba, J. J. (2004). Characterization of molds from dry-cured meat products and their metabolites by micellar electrokinetic capillary electrophoresis and random amplified polymorphic DNA PCR. J. Food Protect. 67, 2234-2239.

Meftah, S., Abid, S., Dias, T., and Rodrigues, P. (2020). Mechanisms underlying the effect of commercial starter cultures and a native yeast on ochratoxin a production in meat products. LWT-Food Sci. Technol. 117:108611. doi: 10.1016/ j.lwt.2019.108611

Mendoza, L. M., Padilla, B., Belloch, C., and Vignolo, G. (2014). Diversity and enzymatic profile of yeasts isolated from traditional llama meat sausages from north-western Andean region of Argentina. Food Res. Int. 62, 572-579. doi: 10.1016/j.foodres.2014.04.008

Moy, Y., Lu, T., and Chou, C. (2012). Volatile components of the enzyme-ripened sufu, a Chinese traditional fermented product of soy bean. J. Biosci. Bioeng. 113, 196-201. doi: 10.1016/j.jbiosc.2011.09.021

Osimani, A., Ferrocino, I., Agnolucci, M., Cocolin, L., Giovannetti, M., Cristani, C., et al. (2019). Unveiling hakarl: a study of the microbiota of the traditional Icelandic fermented fish. Food Microbiol. 82, 560-572. doi: 10.1016/j.fm.2019. 03.027

Parussolo, G., Bernardi, A. O., Garcia, M. V., Stefanello, A., Silva, T. D. S., and Copetti, M. V. (2019). Fungi in air, raw materials and surface of dry fermented sausage produced in Brazil. LWT-Food Sci. Technol. 108, 190-198. doi: 10.1016/ j.lwt.2019.03.073

Perrone, G., and Susca, A. (2017). Penicillium species and their associated Mycotoxins. Methods Mol. Biol. 1542, 107-119. doi: 10.1007/978-1-4939-6707$0 \_5$

Rahmawati, N., Sumardi, I., and Dungani, R. (2020). Isolation and identification of fungi inhabiting rubberimpregnated wood, and their role of quality changing the impregnated Wood. BioResources 15, 2839-2849. doi: 10.15376/biores.15.2. 2839-2849

Roberta, G., Benedetto, M., Silvia, A., Sara, D. T., and Monica, C. (2020). Survey on the presence of Malassezia spp. in healthy rabbit ear canals. Pathogens 9:E696. doi: 10.3390/pathogens 9090696

Rodrigues, P., Silva, D., Costa, P., Abrunhosa, L., Venancio, A., and Teixeira, A. (2019). Mycobiota and mycotoxins in Portuguese pork, goat and sheep dry-cured hams. Mycotoxin Res. 35, 405-412. doi: 10.1007/s12550-019-00 374-8

Ryu, S., Park, M. R., Maburutse, B. E., Lee, W. J., Park, D. J., Cho, S., et al. (2018). Diversity and characteristics of the meat microbiological community on dry aged beef. J. Microbiol. Biotechn. 28, 105-108. doi: 10.4014/jmb.1708.08065

Scaramuzza, N., Diaferia, C., and Berni, E. (2015). Monitoring the mycobiota of three plants manufacturing Culatello (a typical Italian meat product). Int. J. Food Microbiol. 203, 78-85. doi: 10.1016/j.ijfoodmicro.2015.02.034
Segata, N., Izard, J., Waldron, L., Gevers, D., Miropolsky, L., Garrett, W. S., et al. (2011). Metagenomic biomarker discovery and explanation. Genome Biol. 12:R60. doi: 10.1186/gb-2011-12-6-r60

Simoncini, N., Rotelli, D., Virgili, R., and Quintavalla, S. (2007). Dynamics and characterization of yeasts during ripening of typical Italian dry-cured ham. Food Microbiol. 24, 577-584. doi: 10.1016/j.fm.2007.01.003

Simoncini, N., Virgili, R., Spadola, G., and Battilani, P. (2014). Autochthonous yeasts as potential biocontrol agents in dry-cured meat products. Food Control 46, 160-167. doi: 10.1016/j.foodcont.2014.04.030

Toelstede, S., and Hofmann, T. (2009). Kokumi-active glutamyl peptides in cheeses and their biogeneration by Penicillium roquefortii. J. Agr. Food Chem. 57, 3738-3748. doi: 10.1021/jf900280j

Tomás, B., Yolanda, S., M-Concepción, A., and Fidel, T. (2008). Purification and characterisation of Proteases A and D from Debaryomyces hansenii. Int. J. Food Microbiol. 124, 135-141. doi: 10.1016/j.ijfoodmicro.2008.03.001

Tournas, V. H. (2005). Spoilage of vegetable crops by bacteria and fungi and related health hazards. Crit. Rev. Microbiol. 31, 33-44.

Visagie, C. M., Houbraken, J., Frisvad, J. C., Hong, S. B., Klaassen, C. H. W., Perrone, G., et al. (2014). Identification and nomenclature of the genus Penicillium. Stud. Mycol. 78, 343-371. doi: 10.1016/j.simyco.2014.09.001

Wang, X., Wang, S., and Zhao, H. (2019). Unraveling microbial community diversity and succession of Chinese Sichuan sausages during spontaneous fermentation by high-throughput sequencing. J. Food Sci. Tech. Mys. 56, 32543263. doi: 10.1007/s13197-019-03781-y

Wang, X. H., Zhang, Y. L., Ren, H. Y., and Zhan, Y. (2018). Comparison of bacterial diversity profiles and microbial safety assessment of salami, Chinese dry-cured sausage and Chinese smoked-cured sausage by high-throughput sequencing. LWT-Food Sci. Technol. 90, 108-115. doi: 10.1016/j.lwt.2017.12.011

Xie, J. C., Sun, B. G., and Wang, S. B. (2008). Aromatic constituents from Chinese traditional smoke-cured bacon of mini-pig. Food Sci. Technol. Int. 14, 329-340. doi: 10.1177/1082013208098331

Yang, C., Che, Y., Qi, Y., Liang, P., and Song, C. (2017). High-throughput sequencing of viable microbial communities in raw pork subjected to a fast cooling process. J. Food Sci. 82, 145-153. doi: 10.1111/1750-3841.13566

Ye, K. P., Wang, J. J., Han, Y. Q., Qi, C., and Ge, X. Y. (2019). Investigation on microbial contamination in the cold storage room of domestic refrigerators. Food Control 99, 64-67. doi: 10.1016/j.foodcont.2018.12.022

Yi, L. B., Su, G. R., and Hu, G. (2016). Diversity study of microbial community in bacon using metagenomic analysis. J. Food Safety 37:e12334.

Yu, A., and Sun, B. (2005). Flavour substances of Chinese traditional smoke-cured bacon. Food Chem. 89, 227-233. doi: 10.1016/j.foodchem.2004.02.029

Zhu, Y., Cao, Y. Y., Yang, M., Wen, P. C., Cao, L., Ma, J., et al. (2018). Bacterial diversity and community in Qula from the Qinghai-Tibetan Plateau in China. PeerJ 6:e6044. doi: 10.7717/peerj.6044

Conflict of Interest: The authors declare that the research was conducted in the absence of any commercial or financial relationships that could be construed as a potential conflict of interest.

Copyright (c) 2021 Zhang, Qiao, Zhang, Zhang, Wen and Zhu. This is an openaccess article distributed under the terms of the Creative Commons Attribution License (CC BY). The use, distribution or reproduction in other forums is permitted, provided the original author(s) and the copyright owner(s) are credited and that the original publication in this journal is cited, in accordance with accepted academic practice. No use, distribution or reproduction is permitted which does not comply with these terms. 